\title{
Nutrition at Early Stages of Life Determines the Future Growth and Reproductive Performance of Dairy Calves ${ }^{1}$
}

\author{
Philipe Moriel and Fernanda Batistel ${ }^{2}$
}

\section{Introduction}

Studies suggest that improper nutrition in humans immediately after birth may substantially increase the risk for developing obesity, type 2 diabetes, hypertension, and heart disease during adulthood (Lucas 1991). These events occur because a significant portion of organ development is not complete at birth; it continues for the first few months of life. For a calf, nutrition during the first few months of its life may permanently change the way organs develop and have long-term consequences. This process is called metabolic imprinting (Lucas 1991). The concept that metabolic imprinting may permanently affect animal development has substantial economic implications for agriculture, and it should be explored if producers want to improve the performance of animals destined for food production. This fact sheet will summarize some of the research conducted in calf nutrition and nutrition's impact on the growth and reproductive performance of dairy calves.

\section{Newborn Dairy Calf Nutrition}

Dairy calves are born with a naïve adaptive immune system. They have very low concentrations of immunoglobulins and antigen-specific immune cells that aid in recognition and elimination of pathogens. Pathogen-specific immunity of the young calf is acquired from the dam via colostrum. Thus, colostrum intake after birth is crucial to reduce morbidity and death of dairy calves (USDA 2007). Colostrum production begins 5 weeks before calving and its composition differs from that of whole milk in that it contains more protein, immunoglobulins (Ig), fat, vitamins $\mathrm{A}$ and $\mathrm{E}$, and nonnutritive factors such as growth factors and hormones (Davis and Drackley 1998; Elfstrand, Lindmark-Månsson, and Paulsson 2002). Proper colostrum management includes provision of colostrum (IgG concentrations above $50 \mathrm{~g} / \mathrm{L}$; fewer than 100,000 colony-forming units $/ \mathrm{mL}$ ) at $10 \%$ of a calf's body weight (as-fed basis) within 6 hours after birth (USDA 2007). This is equivalent to feeding 1 gallon of colostrum per calf. When those guidelines are not followed, calves do not have adequate immune protection and are more susceptible to disease.

In addition to influencing calf survival and health, colostrum intake during the first hours of a calf's life stimulates maturation and function of the gastrointestinal tract. Each is essential for nutrient absorption and impacts the calf's future performance. For instance, calves that received colostrum had a greater development of the intestinal villus compared with calves fed whole milk (Yang et al. 2015). In addition, calves consuming 3.6 quarts of colostrum at birth had $16 \%$ greater milk production during their second lactation compared to dairy calves given 1.8 quarts of colostrum at birth (Faber et al. 2005). The exact mechanisms by which greater colostrum intake enhanced milk production of dairy cows 2 years later are unknown, but they are likely attributed to metabolic modifications induced by colostrum constituents, such as insulin-like growth factor 1, insulin,

1. This document is AN336, one of a series of the Department of Animal Sciences, UF/IFAS Extension. Original publication date December 2017. Revised November 2021. Visit the EDIS website at https://edis.ifas.ufl.edu for the currently supported version of this publication.

2. Philipe Moriel, associate professor, UF/IFAS Range Cattle Research and Education Center; and Fernanda Batistel, assistant professor, Department of Animal Sciences; UF/IFAS Extension, Gainesville, FL 32611.

The Institute of Food and Agricultural Sciences (IFAS) is an Equal Opportunity Institution authorized to provide research, educational information and other services

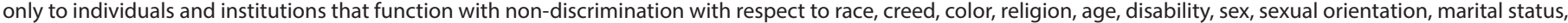

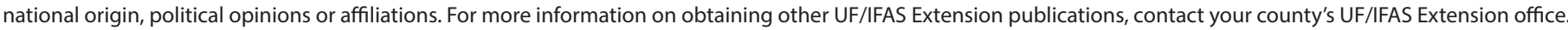
U.S. Department of Agriculture, UF/IFAS Extension Service, University of Florida, IFAS, Florida A \& M University Cooperative Extension Program, and Boards of County Commissioners Cooperating. Nick T. Place, dean for UF/IFAS Extension. 
growth hormone, leptin, and prolactin (Faber et al. 2005; Bach 2012). Although the concentration of hormones and growth factors in whole milk is less than in colostrum (Table 1), it is possible that hormones and growth factors present in whole milk but absent in milk replacer have imprinting effects on the metabolism of calves. Milk production increased by $4 \%$ to $13 \%$ when calves consumed whole milk instead of milk replacer during the first 45 to 60 days of life (Shamay et al. 2005; Moallem et al. 2010).

\section{Conventional and Intensified Nutrition Methods of Dairy Calves}

During the first 45 to 60 days following birth, conventional methods of dairy calf feeding provide relatively low amounts of milk or milk replacer (approximately $10 \%$ of calf body weight, as-fed; crude protein and fat concentration $=20 \%$ to $22 \%$ of dry matter) in order to stimulate the early consumption of concentrate, and consequently, ruminal development (Khan et al. 2007). However, industry focus on "accelerated growth" or "intensified nutrition" in dairy calves has increased substantially during the last decade. Intensive nutrition methods utilize milk replacer with greater concentrations of protein and less fat $(20 \%$ to $30 \%$ crude protein and less than $20 \%$ fat; dry matter basis) that is fed at approximately $20 \%$ of calf body weight as-fed (Brown, Vandehaar, and Daniels 2005; Khan et al. 2007; Tikofsky, Van Amburgh, and Ross 2001), which is similar to the milk consumption of 4 -week-old suckling calves (Hafez and Lineweaver 1968).

The intensified nutrition methods increased lean tissue growth and efficiency of body weight gain (Diaz et al. 2001; Tikofsky, Van Amburgh, and Ross 2001; Rius et al. 2012), and enhanced puberty achievement and future milk production (Brown, Vandehaar, and Daniels 2005; Raeth-Knight et al. 2009; Moallem et al. 2010; Soberon and Van Amburgh 2013). For instance, heifers provided with intensive nutrition had a $45 \%$ increase in average daily gain from 2 to 42 days of age, and were 29 days younger at puberty compared with heifers given conventional milk replacer (Table 2) (Davis-Rincker et al. 2011). In this study, the conventional diet consisted of a standard milk replacer ( $22 \%$ crude protein and fat) fed at $1.2 \%$ of body weight on a dry matter basis, and starter grain ( $20 \%$ crude protein). The intensive diet consisted of a high-protein milk replacer $(31 \%$ crude protein and $16 \%$ fat) fed at $2.1 \%$ of body weight on a dry matter basis, and starter grain $(24 \%$ crude protein). The decreased age at puberty of heifers that received intensive nutrition was observed despite all heifers having a similar body weight as conventionally fed heifers from 12 to 100 weeks of age, which suggests that enhanced nutrition prior to 8 weeks of age had imprinting effects on their reproductive axis and accelerated their puberty achievement.

Enhancing the growth rate of heifers by feeding high-energy diets may decrease age at calving and costs associated with raising replacements. However, a common concern among dairy producers and nutritionists is the accumulation of fat within mammary gland cells due to excessive weight gain. The mammary gland grows at a faster rate than the whole body from 3 to 10 months of age. Consequently, feeding amounts that result in average daily gain above 1.3 $\mathrm{lb} /$ day to $1.5 \mathrm{lb} /$ day may reduce mammary parenchyma mass, enhance fat accumulation in the mammary gland, and decrease subsequent milk production (Sejrsen et al. 2000). However, enhancing the plane of nutrition of calves prior to 60 days of age decreased age at calving without impairing mammary gland growth and milk production. In fact, intensive calf nutrition from birth to 60 days of age enhanced mammary gland growth and milk production at first lactation. Holstein heifers assigned to receive high levels of protein and energy (30\% crude protein and 16\% fat; provided at $2.0 \%$ of body weight on a dry matter basis) from 7 to 49 days of age had greater total parenchyma tissue mass (indicator of mammary gland growth) compared with heifers provided with milk replacer that contained moderate levels of protein and energy ( $21 \%$ crude protein and fat; fed at $1.1 \%$ of body weight on a dry matter basis) (Brown, Vandehaar, and Daniels 2005). In addition, a summary of nine studies demonstrated that daily milk production during first lactation is increased by $326 \mathrm{lb} /$ day for every $0.25 \mathrm{lb} /$ day increase on preweaning average daily gain (ADG)(Gelsinger, Heinrichs, and Jones 2016). In addition, this summary also reported that preweaning ADG seemed to minimally affect milk production when growth rate was below $1.1 \mathrm{lb} /$ day, but had a greater influence as growth rate increased from $1.1 \mathrm{lb} /$ day to $2.0 \mathrm{lb} /$ day.

\section{Economics of Accelerated Growth Programs}

As discussed above, increasing preweaning growth rate may improve future milk production. However, this increase in milk production may not offset the cost of the increased milk or milk replacer intake necessary to achieve greater calf ADG (Heinrichs and Gelsinger 2017).

The following example assumes that milk price does not change from the time of weaning until first calving. For more details about the economic return of increasing 
preweaning growth rate, refer to Heinrichs and Gelsinger (2017). Consider the example of increasing calf ADG from $1.1 \mathrm{lb} /$ day to $1.3 \mathrm{lb} /$ day (Gelsinger, Heinrichs, and Jones 2016). An additional ADG increase of $0.2 \mathrm{lb} /$ day required feeding an additional $12.8 \mathrm{lb}$ of a 20:20 milk replacer, 12.3 $\mathrm{lb}$ of an accelerated milk replacer (27:17), or 10.4 gallons of milk during a 56-day preweaning period. Assuming a cost of $\$ 80$ per 50-lb bag of 20:20 milk replacer and $\$ 100$ per $50-\mathrm{lb}$ bag of accelerated milk replacer, and milk value of $\$ 18 /$ cwt, the cost of increasing preweaning ADG from 1.1 $\mathrm{lb} /$ day to $1.3 \mathrm{lb} /$ day was $\$ 20.45$ (if using 20:20 milk replacer), \$24.53 (27:17 if using an accelerated milk replacer), or $\$ 16.14$ (if using saleable milk) per calf (Heinrichs and Gelsinger 2017). The cost significantly decreased to $\$ 4.04$ / calf if using waste milk (valued at $\$ 4.50 / \mathrm{cwt}$ ). However, the expected increase in milk income from these heifers was only $\$ 3.09 /$ heifer. Positive returns of increasing preweaning growth rate were achieved if enough waste milk was provided to increase preweaning ADG from $1.1 \mathrm{lb} /$ day to $1.5 \mathrm{lb} /$ day or from $1.5 \mathrm{lb} /$ day to $2.0 \mathrm{lb} /$ day (Table 3 ).

Achieving the gains mentioned above is far less expensive if using calf starter (Table 4). Hence, grain feeding is less costly than milk feeding, and the ADG outcomes are the same. Increasing heifer preweaning growth rates, regardless of the feeding strategy, may decrease age at calving and further improve economic return.

In summary, nutrition prior to weaning ( 1 to 45 to 60 days of age) may determine the future performance of dairy calves. Good colostrum management is required to maximize health, but it also impacts the growth and reproductive performance of calves. Providing an intensive nutritional method by increasing the amount and nutritional composition of milk replacer and calf starter from birth to weaning enhances preweaning growth performance, anticipates puberty achievement, and increases future milk production without impairing mammary gland growth.

\section{References}

Bach, A. 2012. "Nourishing and Managing the Dam and Postnatal Calf for Optimal Lactation, Reproduction, and Immunity." J. Anim. Sci. 90:1835-1845. https://doi. org/10.2527/jas.2011-4516

Brown, E. G., M. J. Vandehaar, and K. M. Daniels. 2005. "Effect of Increasing Energy and Protein Intake on Body Growth and Carcass Composition of Heifer Calves." J. Dairy Sci. 88:585-594. https://doi.org/10.3168/jds. S0022-0302(05)72722-3
Davis-Rincker, L. E., M. J. Vandehaar, C. A. Wolf, J. S. Liesman, L. T. Chapin, and M. S. Weber Nielsen. 2011. "Effect of Intensified Feeding of Heifer Calves on Growth, Pubertal Age, Calving Age, Milk Yield, and Economics." J. Dairy Sci. 94:3554-3567. https://doi.org/10.3168/jds.2010-3923

Davis, C. D., and J. K. Drackley. 1998. The Development, Nutrition and Management of the Young Calf. Ames, Iowa: Iowa State University Press.

Diaz, M. C., M. E. Van Amburgh, J. M. Smith, J. M. Kelsey, and E. L. Hutten. 2001. "Composition of Growth of Holstein Calves Fed Milk Replacer from Birth to 105- Kilogram Body Weight." J. Dairy Sci. 84:830-842. https://doi. org/10.3168/jds.s0022-0302(01)74541-9

Elfstrand, L., H. Lindmark-Månsson, and M. Paulsson. 2002. "Immunoglobulins, Growth Factors and Growth Hormone in Bovine Colostrum and the Effects of Processing." Int. Dairy J. 12:879-887. https://doi.org/10.1016/ S0958-6946(02)00089-4

Faber, S. N., N. E. Faber, T. C. McCauley, and R. L. Ax. 2005. "Case Study: Effects of Colostrum Ingestion on Lactational Performance." Applied Anim. Sci. 21:420-425. https://doi.org/10.15232/S1080-7446(15)31240-7

Foley, J. A., and D. E. Otterby. 1978. "Availability, Storage, Treatment, Composition, and Feeding Value of Surplus Colostrum: A Review." J. Dairy Sci. 61:1033-1060. https:// doi.org/10.3168/jds.S0022-0302(78)83686-8

Gasser, C. L., D. E. Grum, M. L. Mussard, F. L. Fluharty, J. E. Kinder, and M. L. Day. 2006. "Induction of Precocious Puberty in Heifers I: Enhanced Secretion of Luteinizing Hormone." J. Anim. Sci. 84:2035-2041. https://doi. org/10.2527/jas.2005-636

Gelsinger, S. L., A. J. Heinrichs, and C. M. Jones. 2016. "A Meta-Analysis of the Effects of Preweaned Calf Nutrition and Growth on First-Lactation Performance." J. Dairy Sci. 99:6206-6214. https://doi.org/10.3168/jds.2015-10744

Hafez, E. S. E., and L. A. Lineweaver. 1968. "Suckling Behaviour in Natural and Artificially Fed Neonate Calves." Z. Tierpsychol. 25:187-198. https://doi. org/10.1111/j.1439-0310.1968.tb00012.x

Heinrichs, A. J., and S. L. Gelsinger. 2017. "Economics and Effects of Accelerated Calf Growth Programs." 28 ${ }^{\text {th }}$ Florida Ruminant Nutrition Symposium. Accessed on December 1, 2017. http://dairy.ifas.ufl.edu/rns/2017/Heinrichs.pdf 
Kehoe, S. I., B. M. Jayarao, and A. J. Heinrichs. 2007. “A Survey of Bovine Colostrum Composition and Colostrum Management Practices on Pennsylvania Dairy Farms."

J. Dairy Sci. 90:4108-4116. https://doi.org/10.3168/ jds.2007-0040

Khan, M. A., H. J. Lee, W. S. Lee, H. S. Kim, K. S. Ki, T. Y. Hur, G. H. Suh, S. J. Kang, and Y. J. Choi. 2007. "Structural Growth, Rumen Development, and Metabolic and Immune Responses of Holstein Male Calves Fed Milk through Step-Down and Conventional Methods." J. Dairy Sci. 90:3376-3387. https://doi.org/10.3168/jds.2007-0104

Lucas, A. 1991. "Programming by Early Nutrition in Man." Ciba Found. Symp. 156:38-50.

Moallem, U., D. Werner, H. Lehrer, M. Zachut, L. Livshitz, S. Yakoby, and A. Shamay. 2010. "Long-Term Effects of Ad Libitum Whole Milk prior to Weaning and Prepubertal Protein Supplementation on Skeletal Growth Rate and First-Lactation Milk Production." J. Dairy Sci. 93:2639-2650. https://doi.org/10.3168/jds.2009-3007

Raeth-Knight, M., H. Chester-Jones, S. Hayes, J. Linn, R. Larson, D. Ziegler, B. Ziegler, and N. Broadwater. 2009. "Impact of Conventional or Intensive Milk Replacer Programs on Holstein Heifer Performance through Six Months of Age and during First Lactation." J. Dairy Sci. 92:799-809. https://doi.org/10.3168/jds.2008-1470

Rius, A. G., H. A. Weeks, J. Cyric, R. M. Akers, B. J. Bequette, and M. D. Hanigan. 2012. "Protein and Energy Intakes Affected Amino Acid Concentrations in Plasma Muscle, and Liver, and Cell Signaling in the Liver of Growing Dairy Calves." J. Dairy Sci. 95:1983-1991. https://doi. org/10.3168/jds.2011-4688

Sejrsen, K. J., S. Purup, M. Vestergaard, and J. Foldager. 2000. "High Body Weight Gain and Reduced Bovine Mammary Growth: Physiological Basis and Implications for Milk Yield Potential." Domest. Anim. Endocrinol. 19:93-104. https://doi.org/10.1016/s0739-7240(00)00070-9

Shamay, A., D. Werner, U. Moallem, H. Barash, and I. Bruckental. 2005. "Effect of Nursing Management and Skeletal Size at Weaning on Puberty, Skeletal Growth Rate, and Milk Production during First Lactation of Dairy Heifers." J. Dairy Sci. 88:1460-1469. https://doi.org/10.3168/jds. s0022-0302(05)72814-9
Soberon, F., and M. E. Van Amburgh. 2013. “The Effect of Nutrient Intake from Milk or Milk Replacer of Preweaned Dairy Calves on Lactation Milk Yield as Adults: A MetaAnalysis of Current Data." J. Anim. Sci. 91:706-712. https:// doi.org/10.2527/jas.2012-5834

Tikofsky, J. N., M. E. Van Amburgh, and D. A. Ross. 2001. "Effect of Varying Carbohydrate and Fat Content of Milk Replacer on Body Composition of Holstein Bull Calves." J. Anim. Sci. 79:2260-2267. https://doi. org/10.2527/2001.7992260x

USDA. 2007. "Heifer Calf Health and Management Practices on U.S. Dairy Operations." Accessed on May 27, 2021. https://www.aphis.usda.gov/animal_health/nahms/dairy/ downloads/dairy07/Dairy07_allpubs.pdf

Yang, M., Y. Zou, Z. H. Wu, S. L. Li, and Z. J. Cao. 2015. "Colostrum Quality Affects Immune System Establishment and Intestinal Development of Neonatal Calves." J. Dairy Sci. 98:7153-7163. https://doi.org/10.3168/jds.2014-9238 
Table 1. Chemical composition of colostrum, transition milk from second milking, and saleable milk.

\begin{tabular}{|l|c|c|c|}
\hline \multicolumn{1}{|c|}{ Item } & Colostrum & Transition Milk: \\
\hline Immunoglobulin G, g/L & 41 & Second Milking & Saleable Milk \\
\hline Fat, \% & 6.7 & 25 & 0.6 \\
\hline Total protein, \% & 14.9 & 5.4 & 3.6 \\
\hline Lactose, \% & 2.5 & 8.4 & 3.2 \\
\hline Vitamin A, ug/g & 4.9 & 3.9 & 4.9 \\
\hline Adapted from Foley and Otterby (1978), Davis and Drackley (1998), and Kehoe, Jayarao, and Heinrichs (2007). & 0.3 \\
\hline
\end{tabular}

Table 2. Average daily gain (lb/day) and age at puberty (days) of heifers given conventional and intensive nutritional methods from 2 to 42 days of age.

\begin{tabular}{|c|c|c|}
\hline \multirow[b]{2}{*}{ Item } & \multicolumn{2}{|c|}{ Nutritional Method } \\
\hline & Conventional & Intensive \\
\hline Average daily gain, lb/day & 0.97 & 1.41 \\
\hline Age at puberty, days & 271 & 300 \\
\hline \multicolumn{3}{|c|}{$\begin{array}{l}\text { Conventional diet consisted of a standard milk replacer ( } 22 \% \text { crude protein and fat) fed at } 1.2 \% \text { of body weight on a dry matter basis and starter grain ( } 20 \% \\
\text { crude protein). Intensive diet consisted of a high-protein milk replacer ( } 31 \% \text { crude protein and } 16 \% \text { fat) fed at } 2.1 \% \text { of body weight on a dry matter basis and } \\
\text { starter grain ( } 24 \% \text { crude protein). }\end{array}$} \\
\hline Adapted from Davis-Rincker et al. (2011). & & \\
\hline
\end{tabular}


Table 3. Estimated feed cost and value of additional milk produced in the first lactation if preweaning growth rate was increased by feeding more milk or milk replacer.

\begin{tabular}{|c|c|c|c|}
\hline \multirow[b]{2}{*}{ Item } & \multicolumn{2}{|c|}{ Change in Growth Rate (lb/day) } & \multirow[b]{2}{*}{1.5 to 2.0} \\
\hline & 1.1 to 1.3 & 1.1 to 1.5 & \\
\hline \multicolumn{4}{|c|}{ Increased feed cost to support greater preweaning growth rate } \\
\hline Milk replacer $(\$ 80 / 50 \mathrm{lb})$ & $\$ 20.45$ & $\$ 41.92$ & $\$ 45.73$ \\
\hline Accelerated milk replacer $(\$ 100 / 50 \mathrm{lb})$ & $\$ 24.53$ & $\$ 50.26$ & $\$ 54.83$ \\
\hline Saleable milk (\$18/cwt) & $\$ 16.14$ & $\$ 33.08$ & $\$ 36.09$ \\
\hline Waste milk (\$4.50/cwt) & $\$ 4.04$ & $\$ 8.27$ & $\$ 9.02$ \\
\hline $\begin{array}{l}\text { Estimated increase in milk yield (lb/ } \\
\text { lactation) }\end{array}$ & 17.2 & 57 & 147.7 \\
\hline Value of additional milk (\$18/cwt) ${ }^{1}$ & $\$ 3.09$ & $\$ 10.26$ & $\$ 26.58$ \\
\hline \multicolumn{4}{|c|}{ Additional milk values minus increased feed cost ${ }^{2}$} \\
\hline Milk replacer (\$80/50 lb) & $\$(17.36)$ & $\$(31.66)$ & $\$(19.15)$ \\
\hline Accelerated milk replacer $(\$ 100 / 50 \mathrm{lb})$ & $\$(21.44)$ & $\$(40.00)$ & $\$(28.25)$ \\
\hline Saleable milk (\$18/cwt) & $\$(13.05)$ & $\$(22.82)$ & $\$(9.51)$ \\
\hline Waste milk (\$4.50/cwt) & $\$(0.95)$ & $\$ 1.99$ & $\$ 17.56$ \\
\hline
\end{tabular}

Table 4. Estimated feed cost and value of additional milk produced in the first lactation if preweaning growth rate was increased by feeding more calf starter.

\begin{tabular}{|c|c|c|c|}
\hline \multirow[b]{2}{*}{ Item } & \multicolumn{3}{|c|}{ Change in Growth Rate (Ib/day) } \\
\hline & 1.1 to 1.3 & 1.1 to 1.5 & 1.5 to 2.0 \\
\hline Total calf starter for greater preweaning ADG (lb/day) & 2.63 & 3.22 & 4.48 \\
\hline Additional calf starter (lb for 56 days) & 30.8 & 63.8 & 70.6 \\
\hline Cost of calf starter (\$/calf) & $\$ 5.56$ & $\$ 11.45$ & $\$ 12.72$ \\
\hline Estimated change in milk yield (lb/lactation) & 17.2 & 57 & 147.7 \\
\hline Value of additional milk (\$18/cwt) & $\$ 3.09$ & $\$ 10.26$ & $\$ 26.58$ \\
\hline Value of additional milk minus cost of calf starter ( $\$ /$ calf) & $\$(2.47)$ & $\$(1.19)$ & $\$ 13.86$ \\
\hline
\end{tabular}

